DOI: http://doi.org/10,21009/JKKP.082.07

\title{
DAMPAK PERCERAIAN ORANGTUA TERHADAP MEANING OF LIFE REMAJA
}

\author{
Afdal $^{\left.1^{*}\right)}$, Roni Yunasril ${ }^{1}$, Shinta Mecha Lestari ${ }^{1}$, Silvia Adila Nusa ${ }^{1}$, Annisa Fortuna \\ Ramadhani $^{1}$, Denia Syapitri ${ }^{1}$ \\ ${ }^{1}$ Universitas Negeri Padang, Kota Padang 25171, Indonesia \\ "E-mail:afdal@konselor.org
}

\begin{abstract}
Abstrak
Pada umumnya konflik selalu terjadi dalam kehidupan rumah tangga, namun konflik yang terjadi merupakan salah satu faktor pemicu terjadinya perceraian. Perceraian tidak hanya berdampak bagi yang bersangkutan (suami istri), namun juga melibatkan anak khususnya yang memasuki usia remaja. Remaja yang orangtuaya bercerai akan mempengaruhi makna hidupnya. Hal ini dikarenakan masa remaja merupakan proses dalam pencarian jati diri mereka dan dimasa inilah ditentukan masa depan dari seorang remaja tersebut. Penelitian ini bertujuan untuk mengetahui bagaimana gambaran dari makna hidup remaja yang menjadi korban dari perceraian kedua orangtua. Metode yang digunakan dalam penelitian ini adalah metode deskriptif kualitatif. Metode ini digunakan untuk melihat dan mendeskripsikan makna hidup remaja yang menjadi korban dari perceraian kedua orangtua. Penelitian ini dilakukan terhadap 4 orang remaja wanita yang orangtuanya bercerai (umur rata-rata 16-18 tahun; berstatus pelajar) melalui wawancara. Data dianalisis dengan model interaktif yang terdiri dari tiga langkah diantaranya rediksi data, penyajian data dan penarikan kesimpulan. Hasil penelitian menunjukkan bahwa keempat informan memiliki pandangan positif dan dapat mengambil hikmah dari setiap kejadian memilukan mengenai perceraian orangtuanya. Meskipun para informan memiliki masa lalu yang kurang baik, dikarenakan mereka mencari pelarian untuk mendapatkan kebahagiaan yang tidak mereka dapatkan di rumah. Positifnya, para informan mampu belajar dari kesalahan-kesalahan di masa lalu dan memiliki keinginan untuk menjadi pribadi yang lebih baik lagi. Terkait dengan temuan ini, para orangtua yang sudah bercerai namun memiliki anak dari hasil pernikahannya, disarankan untuk tetap dan lebih memberikan perhatian, kasih sayang dan kebutuhan anak. Agar anak tetap merasa berharga dan tidak terjerumus dalam hal-hal negatif. Kepada informan untuk dapat mempertahankan dan meningkatkan kerukunan dalam hubungan dengan keluarga dan orang sekitar dengan harapan dapat meningkatkan kebermaknaan hidup pada remaja yang menjadi korban perceraian dari orangtuanya. Konselor juga memiliki peran dalam meminimalisir dampak yang akan terjadi akibat perceraian orangtua bagi remaja, terutama dampak negatif agar membantu remaja untuk dapat memahami kebermaknaan hidup. Layanan Bimbingan dan Konseling yang dapat diberikan yaitu layanan informasi dan layanan konseling individual.
\end{abstract}

Kata kunci: makna hidup, perceraian, remaja

\begin{abstract}
In general, conflict always occurs in domestic life, but the conflict that occurs is one of the triggering factors for divorce. Divorce does not only affect the person concerned (husband and wife), but also involves children, especially those entering their teens. Adolescents whose parents are divorced will affect the meaning of their lives. This is because adolescence is a process in the search for their identity and it is at this time that the future of a teenager is determined. This study aims to find out how the description of the meaning of life for teenagers who are victims of the divorce of their parents. The method used in this study is a qualitative descriptive method. This method is used to see and describe the meaning of life for teenagers who are victims of the divorce of their parents. This research was conducted on 4 young women whose parents divorced (mean age 16-18 years; student status) through interviews. The data were analyzed using an interactive model consisting of three steps including data rediction, data presentation and conclusion drawing. The results showed that the four informants had a positive view and could take lessons from every heartbreaking incident regarding their parents' divorce. Although the informants have a bad past, because they are looking for an escape to get happiness that they don't get at home. Positively, the informants are able to learn from past mistakes and have the desire to become a better person. Related to this finding, parents who are divorced but have children
\end{abstract}


from their marriage are advised to stay and pay more attention, affection and children's needs. So that children still feel valuable and do not fall into negative things. To informants to be able to maintain and improve harmony in relationships with family and people around in the hope of increasing the meaning of life in adolescents who are victims of divorce from their parents. Counselors also have a role in minimizing the impact that will occur due to parental divorce for adolescents, especially the negative impact in order to help teenagers to be able to understand the meaning of life. Guidance and Counseling services that can be provided are information services and individual counseling services.

Keywords: divorce, meaning of life, youth

\section{PENDAHULUAN}

Perceraian dapat diartikan sebagai berakhirnya suatu hubungan suami dan istri yang diputuskan oleh hukum atau agama (talak) karena sudah tidak ada saling ketertarikan, saling percaya serta sudah tidak ada lagi kecocokan satu sama lain sehingga menyebabkan ketidakharmonisan dalam rumah tangga. Wijayanti (2021) mengemukakan bahwa perceraian terjadi karena ada suatu alasan yang melatarbelakanginya. Perceraian sebagai sebuah cara yang harus ditempuh oleh pasangan suami-istri ketika ada masalah dalam huhungan perkawinan mereka tak dapat diselesaikan dengan baik. Perceraian bukanlah tujuan akhir dari suatu perkawinan, akan tetapi sebuah bencana yang melanda mahligai perkawinan antara pasangan suami istri.

Kasus perceraian sering dianggap suatu peristiwa yang menegangkan dalam keluarga. Meningkatnya jumlah kasus perceraian dewasa ini berjalan seiring dengan perubahan gaya hidup, harapan, dan modernisasi. Banyaknya kasus perceraian di Indonesia dapat dilihat dari dari berita, baik itu di TV maupun sosial media. Dilansir dari e-psikologi.com, menyebutkan bahwa kasus perceraian di Indonesia setinggi dengan di Amerika, yaitu mencapai 66,6\%. Menurut Badan Pusat Statistik (2018) kasus perceraian di Indonesia selalu meningkat setiap tahunnya dan pada tahun 2018 tercatat ada 408.202 kasus atau meningkat $9 \%$ dari tahun sebelumnya. Dilansir dari merdeka.com menyebutkan bahwa pada tahun 2019 angka perceraian di Indonesia terkhusunya yang beragama Islam mencapai 480. 618 kasus, sementara pada tahun 2020, per Agustus 2020 telah terdapat 306. 688. Hal ini dapat diartikan bahwa jumlah perceraian di Indonesia rata-rata mencapai seperempat dari dua juta peristiwa pernikahan dalam satu tahun sehingga dapat dikatakan bahwa peristiwa perceraian masih rentan terjadi di Indonesia (Rahmania et al, 2021).

Perceraian tidak hanya berdampak bagi yang bersangkutan (suami-isteri), namun juga melibatkan anak khususnya yang memasuki usia remaja. Perceraian bagi anak apalagi usia remaja merupakan tekanan batin yang sangat menyakitkan, karena pada umumnya setiap anak menginginkan hidup dalam keluarga yang utuh. Anak merasakan kepedihan yang luar biasa dan sangat mendalam (Mone, 2019). Perhatian orang tua kepada anak merupakan hal yang sangat penting. Pengembangan karakter anak merupakan upaya yang perlu melibatkan semua pihak, baik keluarga inti maupun keluarga batin (kakek-nenek), sekolah, masyarakat dan pemerintah. Keterlibatan orangtua sangat diperlukan pada remaja yang tengah dalam perjalanan pencarian jati diri, orangtua dapat membekali anak remaja dengan arahan sehingga remaja tidak cenderung melenceng dalam pencarian identitas dirinya. (Della \& Anizar, 2018). Sehingga peran orangtua menjadi penting dalam tumbuh kembang remaja untuk kedepannya (Jenz \& Apsari, 2021). Menurut Harre dan Lamb (Wardani, 2012) masa remaja merupakan fase idealisme. Untuk itu remaja perlu diberikan edukasi dalam memaknai hidup agar mereka mampu menghadapai permasalan terberat sekalipun. Hal ini dikarenakan masa remaja merupakan proses dalam pencarian jati diri mereka, dan dimasa inilah ditentukan masa depan dari seorang remaja tersebut.

Meaning of life atau makan hidup merupakan salah satu konsep yang penting untuk memahami bagaimana seseorang mengatasi tantangan dalam kehidupan dan memaksimalkan potensi unik yang ada pada dirinya. Fatimah (2018) mengemukakan bahwa 
makna hidup merupakan hal yang sangat pribadi, sehingga dapat selalu berubah-ubah seiring berjalannya waktu dan perubahan situasi dalam kehidupan inidvidu tersebut. Menurut Frankl (Fridayanti, 2013) secara mendasar setiap situasi kehidupan atau kejadian-kejadian yang dialami oleh seseorang memiliki suatu makna. Karena, makna merupakan pencarian dan penemuan eksistensial seseorang. Melalui teori kebutuhan, Baumeister merumuskan satu jenis kebutuhan, yaitu kebutuhan untuk makna (The need for meaning) yang merupakan motivasi untuk memahami sesuatu dalam kehidupan.

Makna hidup seseorang akan berbeda dengan makna hidup orang lain, bahkan akan berbeda dari satu peristiwa dengan peristiwa yang lainnya. Meskipun demikian, manusia memiliki kemampuan untuk menemukan kebermaknaan hidupnya dalam keadaan apapun, bahkan ketika individu harus menghadapi kondisi yang sangat tidak menyenangkan bagi individu tersebut. Pencarian makna hidup merupakan tugas yang membingungkan dan menantang bagi individu. Namun, hal tersebut merupakan prasyarat bagi perkembangan kepribadian individu. Dengan adanya tegangan ini individu yang sehat selalu memperjuangkan tujuan yang memberikan kebermaknaan hidup. Dengan perjuangan yang terusmenerus ini menghasilkan kehidupan yang penuh semangat dan gembira. Tanpa adanya kebermaknaan hidup, manusia tidak memiliki alasan untuk meneruskan kehidupan.

Pada fase tersebut patokan dan nilai-nilai moral masyarakat diteliti, ditantang, bahkan ditolak. Pada masa transisi dan idealisme itulah yang membawa para remaja pada pencarian jati diri, siapa dirinya yang sebenar-nya, sehingga suatu saat akan muncul pertanyaan apakah yang menjadi kebermaknaan hidupnya. Peralihan yang sulit dari masa kanak-kanak ke masa dewasa di satu pihak dan kepekaan mereka terhadap perubahan sosial-historis di pihak lain, maka pencarian identitas pada masa remaja dapat mengarah pada identitas yang stabil, atau bahkan sebaliknya suatu kekacauan peranan atau identitas.

Sehingga, apabila terjadi perceraian didalam suatu keluarga, maka akan mengakibatkan banyak remaja akhir yang mengalami krisis identitas yang akan berujung pada ketidakmampuan remaja untuk memaknai hidupnya. Hal tersebut terkait dengan storm and stress yang dilalui pada masa remaja tersebut, yaitu kondisi sulit menyesuaikan diri, mudah mengalami konflik, merasa bingung, tidak menentu, cemas, depresi, depresi, kacau, pustus asa dan tidak memiliki pegangan yang disebabkan oleh perubahan fluktuatif, baik dari lingkungan fisik maupun sosial. Menurut Anggriany (2006) kebermaknaan hidup remaja dipengaruhi oleh motif-motif sosial yang ada pada dalam diri remaja.

Berdasarkan fenomena di atas, perlu dilakukan riset tentang dampak percerai orangtua terhadap meaning of life remaja. Penelitan ini berupaya untuk mengungkapkan bagaimana gambaran dari makna hidup remaja yang menjadi korban dari perceraian kedua orangtua.

\section{METODE}

Penelitian ini merupakan penelitian deksriptif dengan metode kualitatif. Tujuan dari penelitian deskriptif adalah untuk membuat deskripsi, gambaran atau lukisan secara sistematis, faktual dan akurat mengenai fakta-fakta, sifat-sifat serta hubungan antar fenomena yang diteliti. Adapun responden yang diambil dalam penelitian adalah 4 orang remaja wanita yang orangtuanya bercerai dipilih menggunakan teknik purposive sampling dengan rincian pada tabel 1. Teknik pengumpulan data dalam penelitian ini yaitu dengan wawancara. Wawancara dilakukan untuk mengetahui, untuk melengkapi data dan upaya memperoleh data yang akurat dan sumber data yang tepat. Selanjutnya, data dianalisis melalui empat tahap yaitu pertama, pengumpulan data yang dilakukan melalui hasil wawancara sesuai dengan aspek-aspek yang dikaji terhadap meaning of life remaja; kedua, reduksi data yang merujuk pada proses pemilihan, pemfokusan, penyederhanaan, pemisahan dan pentrasformasian data mentah. Oleh karena itu reduksi data berlangsung selama kegiatan penelitian dilakukan; ketiga, penyajian data dalam konteks ini adalah pengumpulan informasi yang disusun secara 
sistematis dan mudah dipahami, sehingga memberikan kemungkinan menghasilkan kesimpulan; keempat, penarikan kesimpulan yang dilakukan dengan mencatat dan memberikan makna dari yang diwawancarai, memo yang telah ditulis dan lengkapnya pengolahan data, serta pengalaman dalam penelitian ini.

Tabel 1. Responden Penelitian

\begin{tabular}{|c|c|c|c|c|c|c|c|c|}
\hline No. & Inisial & $\begin{array}{c}\text { Jenis } \\
\text { Kelamin }\end{array}$ & Usia & Status & Kelas & Sekolah & $\begin{array}{c}\text { Tanggal } \\
\text { Wawancara }\end{array}$ & Tempat \\
\hline 1. & DJB & Perempuan & 17 th & Pelajar & 3 SMA & $\begin{array}{c}\text { SMA X } \\
\text { PD }\end{array}$ & $\begin{array}{l}\text { Selasa/15 } \\
\text { Juni } 2021\end{array}$ & $\begin{array}{c}\text { Melalui } \\
\text { Telepon }\end{array}$ \\
\hline 2. & $J$ & Perempuan & 16 th & Pelajar & 2 SMA & $\begin{array}{c}\text { SMA X } \\
\text { PD }\end{array}$ & $\begin{array}{l}\text { Selasa/15 } \\
\text { Juni } 2021\end{array}$ & $\begin{array}{l}\text { Melalui } \\
\text { Telepon }\end{array}$ \\
\hline 3. & AN & Perempuan & 16 th & Pelajar & 2 SMA & $\begin{array}{c}\text { MAN X } \\
\text { BNG }\end{array}$ & $\begin{array}{l}\text { Kamis/17 } \\
\text { Juni } 2021\end{array}$ & $\begin{array}{c}\text { Melalui } \\
\text { Telepon }\end{array}$ \\
\hline 4. & $\mathrm{~T}$ & Perempuan & 18 th & Pelajar & 3 SMA & $\begin{array}{c}\text { SMA X } \\
\text { PSM }\end{array}$ & $\begin{array}{c}\text { Rabu/16 } \\
\text { Juni } 2021\end{array}$ & $\begin{array}{l}\text { Melalui } \\
\text { Telepon }\end{array}$ \\
\hline
\end{tabular}

\section{HASIL DAN PEMBAHASAN}

Perceraian didalam suatu keluarga akan mengakibatkan banyak remaja mengalami krisis identitas yang akan berujung pada ketidakmampuan remaja untuk memaknai hidupnya. Frankl (Rahmania et al, 2021) mengemukakan bahwa makna hidup merupakan suatu hal yang bersifat personal, unik dan dianggap penting sehingga memberikan nilai bagi individu itu sendiri. Walaupun terdapat beberapa anak yang sama-sama meiliki orangtua yang bercerai namun makna hidup yang dimiliki akan berbeda-beda. Temuan penelitian ini menggabarkan tentang dampak percerai orangtua terhadap meaning of life remaja Peneliti melakukan wawancara satu kali terhadap responden. Berikut pemaparan dan hasil wawancara penelitian terhadap responden tentang dampak perceraian orangtua terhadap meaning of life :

\section{A. Latar Belakang Perceraian}

1. Responden I

Berdasarkan wawancara dengan DJB, ketika peneliti menanyakan kepada DJB faktor apa yang menyebabkan terjadinya perceraian kedua orangtua DJB, DJB tidak menjawabnya, namun dari hasil wawancara secara tidak langsung telah menggambar-kan bahwa faktor penyebab terjadinya perceraian karena ibunya berselingkuh. Berikut penuturan DJB:

“...meskipun saya jarang tinggal bersama mama dan suami barunya...."

Dari penjabaran yang telah di jabarkan oleh DJB orangtuanya bercerai didukung juga karena perekonomian yang menurun jauh dari sebelumnya, hal di diungkapkan oleh DJB:

"Sejauh ini belum ada yang sesulit menerima keadaan perceraian orangtua saya waktu itu kak. Mungkin masalah perekonomian yang tidak stabil..."

2. Responden II

Lain halnya dengan $\mathrm{DJB}, \mathrm{J}$ tidak mengetahui persis apa penyebab orangtuanya bercerai. Berikut penuturan J: 
"untuk faktornya saya kurang tau kak, karena sampai sekarang saya tidak di beri tahu apa masalah yang menyebabkan orang tua saya bercerai"

Menurut pandangan $\mathrm{J}$ setelah kejadian tersebut ia masih memiliki hubungan baik dengan kedua orangtuanya, ia masih merasa diperhatian oleh kedua orangtuanya, berikut pernyataannya:

"hubungan sama papa baik-baik aja kak, cuma sekarang kayak ada ngerasa ada yang beda aja gitu, karena papa udah ada wanita lain"

3. Responden III

Ketika peneliti menanyakan kepada AN faktor apa yang menyebabkan terjadinya perceraian kedua orangtua AN, jawabannya kemungkinan faktor ekonomi. Berikut penuturan dari AN: "Ya Gara2 faktor ekonomi kak,nah terus ayah tu udah jarang berkerja gitu sampai akhir ini eh waktu saat akhir kemaren-kemaren itu maksudnya kak"

Menurut pandangan AN setelah kejadian tersebut ia masih memiliki hubungan baik dengan kedua orang tuanya, tetapi dengan ayahnya akhir-akhir ini AN menyatakan kurang baik. Berikut pernyataannya dari AN: "Hubungannya dengan ibu baik-baik aja kak, Kalau dengan ayah. Akhir-akhir ini kayaknya kurang baik kak."

4. Responden IV

Ketika peneliti menanyakan kepada $T$ faktor apa yang menyebabkan terjadinya perceraian kedua orangtua $\mathrm{T}$, jawaban dari $\mathrm{T}$ yaitu bahwa ayah $\mathrm{T}$ melakukan perselingkuhan. Berikut penuturan T:

“faktornya, ayah suka main sama cewek di belakang ibu, ibu sakit hati dan marahmarah sama ayah, karena ibu selalu marah-marah di rumah, ayah merasa tidak betah lagi di rumah, terus ayah pai main samo teman-teman ceweknya, nah pas ibu sedang sakit, ibu menelpon ayah untuk di antar pergi berobat,ayah tetap tidak mau untuk pulang ke rumah, sehingga ibu pergi ke kuliner atau kafe, di sana ibu melihat ayah sedang karaoke dengan perempuan, hanya ayah seorang yang laki-laki di sana.

Menurut $\mathrm{T}$ perselingkuhan itu akhirnya di ketahui oleh ibu $\mathrm{T}$, setelah kejadian tersebut ibu T emosinya sering tidak terkontrol, bahkan ibu T sering marah- marah. T berkata seperti ini:

“... iya, ibu suka marah-marah dan tidak terkontol emosinya”

Berdasarkan pemaparan wawancara di atas ditemukam responden DJB orangtuanya bercerai karena ibunya selingkuh, responden $\mathrm{J}$ kurang mengetahui apa penyebab dari perceraian orang tuanya, ia tidak di beri tahu oleh kedua orangtuanya tersebut, responden AN orangtuanya bercerai karena faktor ekonomi dan responden $\mathrm{T}$ penyebab orangtuanya bercerai karena ayahnya selingkuh. Hal ini dapat disimpulkan bahwa latar belakang perceraian kedua orangtua responden adalah karena perselingkuhan dan faktor ekonomi. Hasil penelitian yang dilakukan oleh Harjianto dan Jannah (2019) bahwa faktor yang menyebabkan pasangan suami istri memiliki wanita atau pria idaman lain disebabkan karena kondisi ekonomi yang kurang dan rendahnya pemahaman tentang hak dan kewajiban sebagai seorang suami ataupun istri.

\section{B. Dampak Perceraian Orangtua}

1. Responden I

Hasil wawancara menunjukkan bahwa subjek DJB menjadi lebih cuek dan realistis setelah perceraian orangtuanya. Hal ini sesuai dengan pernyataan DJB sebagai berikut: 
“...Karena sejak kejadian itu saya tipikal orang yang cuek dan bersikap realistis kak. Dan saya tidak suka dengan drama dalam dunia nyata kak. Ibaratnya kek..., kalo...bisa pergi sendiri ya saya perg sendiri. Kalau ndak bisa untuk pergi ya saya tidak memaksakan untuk pergi."

Selain itu, DJB tidak lagi memandang bahwa keluarga yang bahagia adalah keluarga yang lengkap dimana ada ibu, ayah dan saudara yang tinggal bersama. Menurutnya adanya dukungan dan energi positif yang didapatnya sudah membuat dia bahagia, sesuai dengan pernyataannya yaitu:

"...Keluarga itu...yang memberikan hal-hal positif dan support system. Meskipun didalam keluarga itu tidak utuh, tapi ada positif vibes dan support system didalamnya, menurut saya itu keluarga yang real yang seharusnya ada didalam keluarga"

2. Responden II

Hasil wawancara menunjukkan bahwa subjek $\mathrm{J}$ memiliki hubungan yang baik dengan kedua orang tuanya, namun sekarang sejak bercerai ia agak kurang dekat dengan ibunya karena ia tinggal bersama ayahnya. Hal ini sesuai dengan apa yang di sampaikannya:

"papa sama kayak ibu, baik banget orangnya, sayang juga sama aku, apapun yang aku minta dia selalu berusaha untuk menurutinya"

Selain itu, J tidak lagi memandang bahwa keluarga yang bahagia adalah keluarga yang lengkap dimana ada ibu, ayah yang harus ribut terus. Bagi J keluarga yang baik itu di mana kedua orang tua bisa saling mengerti bagaimana keadaan anaknya, sesuai dengan pernyataannya yaitu:

"bagi aku keluarga itu bisa tinggal bersama dengan kedua orang tua, ga harus liat orang tua ribut tiap hari, bagi aku kluarga yang baik itu di mana orang tua bisa saling mengerti dan paham bagaimana keadaan anaknya"

3. Responden III

Hasil wawancara menunjukkan bahwa subjek AN memiliki hubungan yang baik dengan kedua orang tuanya,. Hal ini sesuai dengan apa yang di sampaikannya:

"saya dekat dengan ibu kak,ibu segalanya bagiku,kalau dengan ayah sama seperti ibu kak saya juga dekat denganku ayah segala-galanya bagiku kak"

Selain itu, faktor orang tuanya bercerai yaitu dikarenakan faktor ekonomi dan AN memandang jika keluarga yang baik itu seharusnya tidak mempermasalahkan itu, dan AN memandang keluarga itu seharusnya, seperti yang sisampaikan oleh annisa yaitu:

"keluarga itu yang harus harmonis, bahagia banyak waktu untuk berkomunikasi kak"

4. Responden IV

Hasil wawancara menunjukkan bahwa $T$ menjadi terasingkan oleh ayahnya setelah perceraian orangtuanya, bahkan $T$ mencari uang sendiri untuk memenuhi kehidupanya dan terpaksa $T$ tidak bisa melanjutkan pendidikanya ke jenjang yang lebih tinggi. Hal ini sesuai dengan pernyataan dia sebagai berikut:

“....dengan ayah, tidak pernah saling tegur sapa dengan ayah (kerja keras, bisa menyekolah adik adik, dan bisa menunjukan samo orangtua kalo $T$ bisa, intinya setelah perceraian ko T tidak bisa untuk kuliah"

" ibu tidak pernah peduli lagi samo $T$, karena saat ini $T$ tingga sendiri"

Selain itu, $\mathrm{T}$ tidak lagi memandang bahwa keluarga yang bahagia adalah keluarga yang lengkap dimana ada ibu, ayah dan saudara yang tinggal bersama. $\mathrm{T}$ 
berharap agar keluarganya bisa utuh kembali seperti keluarga pada umunya,dan ayahnya sadar akan kesalahanya sesuai dengan pernyataannya yaitu:

“...harapanya agar orang tua bisa rujuk lagi, ayah sadar akan kesalahanyam dan keluarga bisa utuh lagi"

Berdasarkan pemaparan wawancara di atas dapat disimpulkan bahwa dampak perceraian terhadap responden DJB menjadi lebih cuek dan realistis, responden J agak kurang dekat dengan ibunya karena ia tinggal bersama ayahnya, responden AN kecewa dengan keputusan yang diambil orangtuanya untuk bercerai dan responden $T$ menjadi terasingkan oleh ayahnya setelah perceraian orangtuanya dan terpaksa bekerja untuk kebutuhan sehari-hari. Ibda dan Nastakin (2020) mengemukakan bahwa remaja yang orangtuanya bercerai akan mengalami kebigungan dalam mengambil keputusan, remaja cenderung mengalami frustasi karena kebutuhan dasarnya seperti perasaan ingin disayangi, dilindungi rasa aman, dan dihargai telah tereduksi bersamaan dengan peristiwa perceraian orangtuanya. Keluarga yang tidak harmonis merupakan faktor penentu bagi perkembangan kepribadian remaja yang tidak sehat. Dampak yang dialami remaja ketika orangtuanya bercerai diantaranya anakbisa mmebeci orantuanya dan berani sama orangtuanya.

\section{Pandangan Subjek terhadap Perceraian Orangtua}

1. Responden I

Pandangan DJB sebagai seorang remaja yang masih duduk di bangku SMA mengenai perceraian yang terjadi antara kedua orangtuanya mengatakan bahwa DJB sangat merasa sedih akan keadaan yang sedang DJB alami, hal ini bisa di lihat dari pernyataan DJB:

"Waktu awal-awal saya sangat sedih kak dan menanyakan pada diri sendiri dan juga kakak "kok itu bisa terjadi di keluarga kita". Apalagi waktu tu saya di rumah hanya dengan adek. Karen kakak pertama saya di Jakarta dan kakak saya satunya lagi di Jepang. Jadi saya bingung harus bersikap apa dan saya hanya terus marah dengan keadaan yang terjadi"

2. Responden II

Pandangan $\mathrm{J}$ sebagai seorang remaja yang masih duduk di bangku kelas 2 SMA mengenai perceraian yang terjadi antara kedua orang tua $\mathrm{J}$ mengatakan bahwa $\mathrm{J}$ sangat merasa sedih akan keadaan yang sedang $\mathrm{J}$ alami, hal ini bisa di lihat dari pernyataan $\mathrm{J}$ :

"awalnya sedih kak, siapa coba yang mau orang tuanya pisah, tapi mau gimana lagi, itu udah jadi keputusan orang tua aku kak"

Selanjutnya peneliti bertanya pada $\mathrm{J}$ apa yang permasalahan yang paling berat di alami $\mathrm{J}$ setelah terjadinya perceraian antara kedua orang $\mathrm{J}$, $\mathrm{J}$ mengatakan bahwasanya akibat dari perceraian kedua orangtuanya $\mathrm{J}$ kurang bisa mengatur waktu makan, karena masih sering kepikiran dengan orangtuanya, namun untuk permasalahan di sekolah ia tidak memiliki dampak masalah bagi dirinya. Hal ini dapat di lihat dari pernyataan J:

"kalau bagi aku, ya ngatur jam makan gitu kak,biasanya apa-apa makan aku di siapi sama ibu, tapi sekarang ibu pergi dari rumah, dan aku berdua sama ayah, jadi kadang makan aku suka ga terartur gitu" 


\section{Responden III}

Pandangan AN sebagai seorang remaja yang masih duduk di bangku kelas 2 SMA mengenai perceraian yang terjadi antara kedua orangtua AN mengatakan bahwa AN berat menerima perceraian orangtuanya, hal ini bisa di lihat dari pernyataan AN:

"Pastinya sangat berat kak untuk menerimanya"

Selanjutnya peneliti bertanya pada $\mathrm{AN}$ apa yang permasalahan yang paling berat di alami AN setelah terjadinya perceraian antara kedua orangtua AN, AN merasa masalah mental dan hidupnya merasa terpuruk akan hal itu. Hal ini dapat di lihat dari pernyataan AN:

"Tentunya masalah mental, masalah biaya hidup, biaya kelanjutan sekolah juga kak soalnya ayah udah jarang bekerja yaa gitulah kak"

4. Responden IV

Pandangan T sebagai seorang remaja yang masih duduk di bangku kelas 3 SMA mengenai perceraian yang terjadi antara kedua orangtua $T$ mengatakan bahwa $T$ sangat merasa sedih akan keadaan yang sedang $T$ alami, hal ini bisa di lihat dari pernyataan $\mathrm{T}$.

"Perasaan T merasa sedih. Lebih baik bercerai dari pada bertengkar terus, perasaan Thancur, sedih, melihat keluarga T tidak utuh lagi"

Selanjutnya peneliti bertanya pada $T$ apa yang permasalahan yang paling berat di alami $T$ setelah terjadinya perceraian antara kedua orangtua $T$, $T$ mengatakan bahwasanya akibat dari perceraian kedua orangtuanya $T$ tidak bisa melanjutkan pendidikanya ke tingkat yang lebih tinggi. Hal ini dapat di lihat dari pernyataan T

"masalah ketika ingin kuliah, tapi karena keadaan orang tua"

Berdasarkan hasil wawancara di atas dapat disimpulkan bahwa keempat responden sangat merasa sedih dan berat menerima perceraian kedua orangtuanya. Hasil penelitian ini diperkuat dengan hasil penelitian yang dilakukan oleh Mone (2019) hasil tersebut menunjukkan bahwa anak merasa ketakutan karena kehilangan sosok ayah atau ibu mereka. Takut kehilangan kasih sayang orangtua yang kini tidak tinggal serumah. Dampak perceraian yang dirasakan oleh anak-anak antara lain: sedih, kesepian, dan kecewa. Beberapa remaja yang orangtua bercerai belum dapat menerima perceraian orangtuanya akan memiliki keinginan yang sangat besar untuk mewujudkan keluarga menjadi normal kembali dengan membujuk agar kedua orangtuanya rujuk. Pada sebagian remaja mungkin ada yang melakukan cara-cara yang mengarah pada tindakan merugikan diri sendiri karena merasa gagal menyatukan kedua orangtuanya kembali. Adanya berbagai reaksi pada remaja terhadap perceraian orangtua berkaitan erat dengan penerimaan individu terhadap perceraian (Untari et al, 2018).

\section{Meaning of Life Subjek Setelah Perceraian}

1. Responden I

Percerain yang terjadi antara orangtua DJB berpengaruh terhadap makna hidup (meaning of life) DJB kearah yang mandiri dan berpikiran dewasa dari yang sebelumnya, Hal ini dukung oleh pernyataan DJB:

"pandangan hidup saya sekarang ini.... Saya...bisa menerima dengan legowo ekspektasi yang tidak sesuai. Dan saya rasa pikiran saya jadi lebih terbuka kak." 
Kemudian ketika ditanya bagaiama DJB menerima keadaan yang sedang dia alami ini, DJB mengatakan dia menerima keadaan ini dengan selalu bersyukur menghadapi keadaan baik itu masa lalu, sekarang atau yang akan datang. Hal ini dapat dilihat dari pernyataan DJB:

"Bersyukur itu kunci yang utama kak. Dan belajar dari perjalanan kehidupan orang lain kak. Saya sering liat podcas di youtube gitu kak. Jadi ternyata diluar sana ada masalah yang lebih sulit dan besar dibandingkan saya kak. Dari situ saya belajar untuk menerima semuanya dengan bersyukur kak"

Dari hal tersebut dapat di ketahui bahwa DJB menerima dengan iklhas akan keadaan yang sedang di alami keluarganya, dengan keadaan ini DJB menjadi sosok pribadi yang lebih dewasa, mandiri, dan memiliki prinsip untuk pegangan hidupnya.

2. Responden II

Percerain yang terjadi antara orangtua $\mathrm{J}$ berpengaruh terhadap makna hidup (meaning of life) $\mathrm{J}$, peneliti bertanya bagaimana pandangan hidup $\mathrm{J}$ terhadap percearian kedua orang tua, $\mathrm{J}$ mengatakan bahwa untuk saat sekang ini $\mathrm{J}$ akan lebih mandiri, memberikan hal yang terbaik menurut $\mathrm{J}$, menunjukan kepada kedua orangtua $\mathrm{J}$ bahwasanya $\mathrm{J}$ bisa yang mandiri dan dewasa dengan keadaan seperti ini. Hal ini dukung oelh pernyataan J:

"menjadi anak yang sukses, yang akan membuktikan kepada orang banyak walaupun aku anak broken home, tapi aku bisa sukses seperti mereka"

Kemudian ketika ditanya bagaiama $\mathrm{J}$ menerima keadaan yang sedang dia alami ini, J mengatakan dia menerima keadaan ini dengan sabar, ikhklas menjalani, berapun penyesalanya, tangisnya, tidak akan memberikan solusi. Hal ini dapat dilihat dari pernyataan $\mathrm{J}$ :

"ya gak gimana-gimana kak, lebih ke jalani hidup sebaik mungkin, di mana bisa ngebahagiain diri sendiri, tanpa membebankam orang lain, tanpa membebankan orang tua, itu aja sih kak"

Dari hal tersebut dapat di ketahui bahwasanya $\mathrm{J}$ menerima dengan iklhas akan keadaan yang sedang di alami $\mathrm{J}$, dengan keadaan ini $\mathrm{J}$ menjadi sosok ptibadi yang lebih dewasa, mandiri, dan memiliki prinsip percaya diri yang lebih tinggi.

3. Responden III

Percerain yang terjadi antara orangtua AN berpengaruh terhadap makna hidup (meaning of life) AN, peneliti bertanya bagaimana pandangan hidup AN terhadap percearian kedua orang tua, AN mengatakan bahwa. Setelah Orangtua AN bercerai tentu AN merasa ada yang mempengharui hidupnya yaitu terutama masalah mental ia sebagai seorang anak, AN merasa diejek oleh teman-temannya. Dari kejadian itu ia mempunyai prinsip yaitu harus berguna bagi agama dan bangsa, lalu semua itu sudah ada yang mengatur kehidupannya. Sesuai dengan dari pernyataannya yaitu:

"Saya ingin menjadi orang yang berguna bagi agama dan bangsa kak, dan saya menerima keadaan sekarang dengan mempunyai prinsip bahwa saya menerima dengan ikhlas dan lapang dada, karena semua sudah takdir dan sudah ditetapkan jalannya oleh Allah SWT"

Didalam pemenuhan hidupnya AN menjalani hidup seperti biasa walaupun ada beberapa kendala seperti perekonomiannya yang kurang stabil, seperti yang ia sampaikan yaitu:

"Proses pemenuhan hidupnya seperti biasa, saya tetap belajar dengan giat dan membimbing adik-adik saya" 
Lalu AN mempunyai prinsip yang bagus didalam hidupnya, walaupun orangtua ia bercerai tetapi ia tidak menjadi anak yang broken home pada umumnya yang terkadang hidupnya menjadi tidak terarah, tetapi tidak dengan $\mathrm{AN}$, berikut pernyataan dari AN:

"Prinsip saya yaitu Diam, kerjakan dan Buktikan kak"

4. Responden IV

Percerain yang terjadi antara orangtua $T$ berpengaruh terhadap makna hidup (meaning of life) T, peneliti bertanya bagaimana pandangan hidup $\mathrm{T}$ terhadap percearian kedua orang tua, T mengatakan bahwa untuk saat sekang ini T akan lebih mandiri, memberikan hal yang terbaik menurut $\mathrm{T}$, menunjukan kepada kedua orang tua $T$ bahwasanya $T$ bisa yang mandiri dan dewasa dengan keadaan seperti ini. Hal ini dukung oelh pernyataan $\mathrm{T}$ :

"agar bisa kuat menjalani cobaan yang sedang di uji tuhan, bisa menunukan sama orang tua, kalau T bisa tanpa orang tua, menjalani apo yang sedang di alami dengan ikhlas, .. kerja keras, bisa menyekolah adik adik, dan bisa menunjukan samo orang tua kalo T bisa"

Kemudian ketika ditanya bagaiama T menerima keadaan yang sedang dia alami ini, T mengatakan dia menerima keadaan ini dengan sabar, ikhklas menjalani, berapun penyesalanya, tangisnya, tidak akan memberikan solusi. Hal ini dapat dilihat dari pernyataan $\mathrm{T}$ :

"..sabar, ikhklas menjalani, berapun penyesalanya, tangisnya, tidak akan memberikan solusi, Cuma ini jalanya, karena sudah di takdirkan, dan berpikir positif aja"

Dari hal tersebut dapat di ketahui bahwasanya T menerima dengan iklhas akan keadaan yang sedang di alami $\mathrm{T}$, dengan keadaan ini T menjadi sosok ptibadi yang lebih dewasa, mandiri, dan memiliki prinsip percaya diri yang lebih tinggi. Sesuai pernyataan $\mathrm{T}$ seperti berikut:

" prinsip sekarang, tidak mendengarkan apa yang di sampaikan orang lain tentang keluarga, orang tua, selagi itu benar, tetap jalani hidup ini, menjalani apo yang sedang di alami dengan ikhlas, kerja keras, bisa menyekolah adik adik, dan bisa menunjukan samo orang tua kalo T bisa"

Berdasarkan hasil wawancara di atas dapat disimpulkan bahwa keempat reponden mensyukuri peristiwa tidak menyenangkan dalam hidup yaitu perpisahan kedua orang tua yang tidak diinginkan dan diharapkan oleh siapapun. hal tersebut dapat memberikan dorongan dan motivasi pada diri remaja yang orangtuanya berpisah. Kehendak diri untuk tidak menyalahkan siapapun dalam peristiwa bercerainya kedua orangtua responden. Memahami bahwa keputusan kedua orangtua responden adalah keputusan dan jalan keluar terbaik dalam hidup. Meskipun para informan merasa kecewa dan sedih, mereka hanya bisa mendoakan dan memberikan dukungan yang positif.

Ketika remaja tumbuh dalam keluarga yang bercerai, mereka mengembangkan keraguan tentang cinta dan keharmonisan dalam hubungan. Mereka merasa sulit untuk menyelesaikan konflik hubungan karena masalah kepercayaan (Widiastuti, 2015). Remaja sebenarnya membutuhkan peran orangtua, jika tidak sempurna untuk mengontrol interaksinya maka teman sebaya berperan dalam mempengaruhi kehidupan sosial mereka nantinya. Remaja yang tidak memiliki atau telah menemukan makna dalam hidupnya akan sulit menerima keputusan orangtuanya untuk berpisah. Remaja akan kesulitan untuk melihat sisi baik dari perpisahan tersebut. Mahrani et al (2021) mengemukakan bahwa perceraian yang dirasakan anak merupakan tekanan batin yang sangat menyakitkan, karena pada umumnya setiap anak menginginkan hidup dalam keluarga yang utuh, adanya kehadiran orangtua di 
sepanjang perjalanan kehidupannya. Anak yang orangtuanya bercerai mengalami hidup yang tidak sehat secara mental dan tidak bahagia. Anak merasakan kepedihan yang luar biasa dan sangat mendalam.

Mayoritas remaja korban perceraian orangtuanya cenderung memilih yang negatif menurut mereka menyenangkan tapi sebenarnya tidak baik. Meaning of life merupakan bagian dari keadaan psikologis seseorang. Situasi ini dapat membimbing remaja untuk lebih memahami dan mengambil keputusan tentang setiap langkah kehidupan agar lebih produktif dan bahagia. Meaning of life manusia juga unik dan setiap remaja memiliki makna yang berbeda dalam kehidupan satu sama lain, bahkan dalam menghadapi situasi atau kondisi yang sama. Meaning of life seringkali tercapai setelah melalui proses panjang dalam kehidupan remaja. Setelah mereka dewasa, mereka dapat memahami dan belajar dari peristiwa yang terjadi (Rachmawati, 2016).

Meaning of life menjadi salah satu bagian terpenting dalam kehidupan seseorang karena dengan adanya makna hidup manusia merasa lebih mampu dan lebih kuat dari sebelumya dalam menjalani kehidupan yang tidak menyenangkan. Meaning of life dianggap penting, memberikan nilai khusus didambakan orang dalam hidupnya (Bastaman, 2007). meaning of life diwujudkan dalam keinginan untuk berguna bagi orang lain dan diri kita sediri (Allport, 2003). Dasar dari kebermaknaan hidup anak korban perceraian kedua orangtuanya adalah selalu merasa bersyukur, maka dengan bersyukur mereka akan merasa lebih ikhlas dalam menjalani kehidupan meskipun terkadang tidak sesuai dengan apa yang diharapkan. Selain itu dengan membantu sesama, mengurangi beban orang lain dengan kemampuan yang dimiliki adalah hal yang membahagiakan dan membanggakan bagi seorang anak yang kedua orang uanya bercerai. Dengan dasar meaning of life yang berbeda dapat membentuk anakanak korban perceraian menjadi individu yang lebih mampu dan lebih kuat dari sebelumnya. Karna, jika remaja belum bisa memahami makna hidup, maka mereka akan lebih mudah menyerah, putus asa, dan bahkan dapat mengganggu psikisnya.

Berdasarkan hasil dan pembahasan penelitian, perlu dilakukan upaya-upaya meminimalisir dampak yang akan terjadi akibat perceraian orangtua bagi remaja, terutama dampak negatif agar membantu remaja untuk dapat memahami kebermaknaan hidup. Upaya ini perlu dilakukan oleh segenap eleman di sekolah. Meskipun bukan satu-satunya penentu lahirnya orang-orang kreatif, guru yang berperan sebagai pengajar dan pembimbing siswa, bertanggung jawab dalam mengambngkan kreativitas siswa tersebut, biak melaui pembelajaran di kelas secara mandiri maupun melalaui kegiatan kolaboratif dengan pihak terkait (Afdal, 2015). Proses pemberian bantuan yang dilakukan konselor/guru BK kepada klien (siswa) melalui bimbingan konseling permasalahan-permasalahan remaja yang berkaitan dengan kebermaknaan hidup serta dampak perceraian bisa terentaskan dengan cara pemberian layanan yang sesuai untuk klien yang mengalami masalah. Pelayanan bantuan yang diberikan berkenaan dengan pengembangan kondisi kehidupan efektif seharihari (KES) dan penenganan kondisi kehidupan efektif sehari-hari yang terganggu (KES-T), baik secara perorangan maupun kelompok, agar mampu mandiri dan berkembang secara optimal dalam bidang pengembangan kehidupan pribadi, kehidupan sosial, kemampuan belajar dan perencanaan karir, melalui berbagai jenis layanan dan kegiatan pendukung berdasarkan norma-norma yang berlaku (Prayitno et al, 2017).

Layanan Bimbingan dan Konseling yang dapat diberikan yaitu layanan informasi dan layanan konseling individual. Prayitno dan Amti (2015) menjelaskan bahwa layanan informasi memberikan pemahaman kepada individu-individu yang berkepentingan tentang berbagai hal yang diperlukan untuk menjalani suatu tugas atau kegiatan atau untuk menentukan arah suatu tujuan atau rencana yang dikehendaki. Sehingga dapat dikatakan bahwa fungsi utama dari layanan informasi adalah fungsi pemahaman. Dalam layanan ini konselor dapat memberikan berbagai informasi mengenai cara menimalisir dampak akibat perceraian orangtua bagi remaja, terutama dampak negatif agar membantu remaja untuk dapat memahami kebermaknaan hidup. Layanan konseling individual dapat dilakukan oleh konselor jika terdapat 
masalah atau informasi yang ingin diceritakan berkenaan dengan kebermaknan hidup bagi remaja korban perceraian orangtua. Menurut Sitorus (2021) konseling inidvidual yaitu layanan yang diberikan kepada klieni melalui hubungan secara pribadi dengan proses wawancara guna untuk teratasinya masalah klien dan menjadikan klien mandiri dalam mengatasi masalahnya. Berdasarkan tujuan konseling individual di atas, dapat disimpulkan bahwa konseling inidvidual pada hakikatnya bersifat membantu yang mana konselor membantu klien dalam mengentaskan permasalahan yang sedang dihadapinya secara optimal.

\section{SIMPULAN DAN SARAN}

Hasil penelitian menunjukkan bahwa keempat informan memiliki pandangan positif dan dapat mengambil hikmah dari setiap kejadian memilukan mengenai perceraian orangtuanya. Meskipun para informan memiliki masa lalu yang kurang baik, dikarenakan mereka mencari pelarian untuk mendapatkan kebahagiaan yang tidak mereka dapatkan di rumah. Positifnya, para informan mampu belajar dari kesalahan-kesalahan di masa lalu dan memiliki keinginan untuk menjadi pribadi yang lebih baik lagi. Terkait dengan temuan ini, para orangtua yang sudah bercerai namun memiliki anak dari hasil pernikahannya, disarankan untuk tetap dan lebih memberikan perhatian, kasih sayang dan kebutuhan anak. Agar anak tetap merasa berharga dan tidak terjerumus dalam hal-hal negatif. Kepada informan untuk dapat mempertahankan dan meningkatkan kerukunan dalam hubungan dengan keluarga dan orang sekitar dengan harapan dapat meningkatkan kebermaknaan hidup pada remaja yang menjadi korban perceraian dari orang tuanya. Konselor juga memiliki peran dalam meminimalisir dampak yang akan terjadi akibat perceraian orangtua bagi remaja, terutama dampak negatif agar membantu remaja untuk dapat memahami kebermaknaan hidup. Layanan Bimbingan dan Konseling yang dapat diberikan yaitu layanan informasi dan layanan konseling individual.

\section{DAFTAR PUSTAKA}

Afdal, A. (2015). Kolaboratif: Kerangka Kerja Konseor Masa Depan. Jurnal Konseling dan Pendidikan, 3(2), 1-7.

Allport, W. (2003). Logoterapi: Terapi psikologi melalui Pemaknaan Eksistensi. Penerjemah: Djamaludin. Jakarta: : Kreasi. Wacana.

Anggriany, N. (2006). Motif Sosial dan Kebermaknaan Hidup Remaja Pagaralam. Psikologika: Jurnal Pemikiran dan Penelitian Psikologi, 11(21), 51-63.

Bastaman, H. D. (2007). Logoterapi: Psikologi untuk Menemukan Makna Hidup dan Meraih Hidup Bermakna. Jakarta: Raja Grafindo Persada.

Della, N. A., \& Anizar, R. (2018). Hubungan Dukungan Sosial dan Konsep Diri Dengan Penyesuaian Diri Remaja Kelas X SMA Angkasa 1 Jakarta. Ikraith-Humaiora, 2(3).

Fatimah, M. (2018). Kebahagiaan Ditlnjau dari Status Pernikahan Kebersamaan hidup. Jurnal Psikologi, 14(2).

Fridayanti. (2013). Pemaknaan Hidup (Meaning in Life) Dalam Kajian Psikologi. Psikologika: Jurnal Pemikiran dan Penelitian Psikologi, 18(2), 189-198.

Harjianto, H., \& Jannah, R. (2019). Identifikasi Faktor Penyebab Perceraian Sebagai Dasar Konsep Pendidikan Pranikah di Kabupaten Banyuwangi. Jurnal IIm. Univ. Batanghari Jambi, 19(1).

Ibda, H., \& Nastakin, S. (2020). Damapak Perceraian Orantua Terhadap Minat Belajar Anak di Desa Ngadisepi. Jurnal Kajian Agama Hukum dan Pendidikan Islam, 2(2), 1-8.

Jenz, F., \& Apsari, N. C. (2021). Dampak Perceraian Orangtua pada Prestasi Anak Remaja. JJPM (Jurnal Pengabdian dan Penelitian Kepada Masyarakat, 2(1), 1-10. 
Mahrani, L., Batubara, A., \& Muhazir. (2021). Perkembangan Emosi pada Anak Korban Perceraian Orangtua pada Lingkungan 1 Kelurahan Damai Kecamatan Binjai Utara Kota Binjai. Jurnal Serunai Bimbingan dan Konseling, 10(1), 17-25.

Mone, H. F. (2019) Dampak Perceraian Orangtua terhadap Perkembangan Psikososial dan Prestasi Belajar. Harmoni Sosial: Jurnal Pendidikan IPS, 6(2), 155-163.

Prayitno., \& Amti, E. (2015). Dasar-dasar Bimbingan dan Konseling. Jakarta: Rineka Cipta.

Prayitno., Afdal., Ifdil., \& Ardi, Z. (2017). Layanan Bimbingan Kelompok dan Konseling Kelompok yang Berhasil. Jakarta: Ghalia Indonesia.

Rachmawati, A. P. (2016). Penemuan Makna Hidup pada Insan Pasca Stroke. Jurnal Psikologi Ulayat, 3(2), 181-194.

Rahmania, F. A., Hizbullah, K., Anisa, S. N., \& Wahyuningsih, H. (2021). The Effects of Forgiveness and Self-Acceptance On the Meaning of Life in Early Adult Individuals with Divorced Parents. Proceding of Inter-Islamic University Conference On Psychology, 1(1), 1-8.

Sitorus, M. W. (2021). Konseling Individu dalam Meningkatkan Kepercayaan Diri Siswa Korban Kekerasan di Madrasah Ibtidaiyah Al-Afkari. Jurnal MUDABBIR, 1(1), 32-37.

Untari, Putri, K. P., \& Hafiduddin, M. (2018). Dampak Perceraian Orangtua terhadap Kesehatan Psikologis Remaja. Media Publikasi Penelitian, 15(2), 99-106.

Wardani, I. R. K. (2012). Hubungan Cita Rasa Humor (Sense of Humor) Dengan Kebermaknaan Hidup pada Remaja Akhir (Mahasiswa). Jurnsal Sosiohumaniora, 3(3), 78-88.

Widiastuti, R. Y. (2015). Dampak Perceraian pada Perkembangan Sosial dan Emosional Anak usia 5-6 Tahun. Jurnal Pendidikan dan Pembelajaran Anak Usia Dini, 2(2), 76-86.

Wijayanti, U. T. (2021). Analisis Faktor Penyebab Perceraian pada Masa Pandemi Covid-19 di Kabupaten Banyumas. Jurnal IImiah Keluarga dan Konseling, 14(1), 14-26. 